\title{
Estimating aquifer properties and distributed groundwater recharge in a hard-rock catchment of Udaipur, India
}

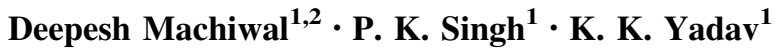

Received: 3 March 2016/Accepted: 31 August 2016/Published online: 13 September 2016

(c) The Author(s) 2016. This article is published with open access at Springerlink.com

\begin{abstract}
The present study determined aquifer parameters in hard-rock aquifer system of Ahar River catchment, Udaipur, India by conducting 19 pumping tests in largediameter wells. Spreadsheet programs were developed for analyzing pumping test data, and their accuracy was evaluated by root mean square error (RMSE) and correlation coefficient $(R)$. Histograms and Shapiro-Wilk test indicated non-normality ( $p$ value $<0.01$ ) of pre- and postmonsoon groundwater levels at 50 sites for years 2006-2008, and hence, logarithmic transformations were done. Furthermore, recharge was estimated using GISbased water table fluctuation method. The groundwater levels were found to be influenced by the topography, presence of structural hills, density of pumping wells, and seasonal recharge. The results of the pumping tests revealed that the transmissivity $(T)$ ranges from $68-2239 \mathrm{~m}^{2} / \mathrm{day}$, and the specific yield $\left(S_{\mathrm{y}}\right)$ varies from 0.211 to $0.51 \times 10^{-5}$. The $T$ and $S_{\mathrm{y}}$ values were found reasonable for the hard-rock formations in the area, and the spreadsheet programs were found reliable (RMSE $\sim 0.017-0.339 \mathrm{~m} ; R>0.95)$. Distribution of the aquifer parameters and recharge indicated that the northern portion with high ground elevations (575-700 m MSL), and high $S_{\mathrm{y}}(0.08-0.25)$ and $T\left(>600 \mathrm{~m}^{2} /\right.$ day $)$ values may act as recharge zone. The $T$ and $S_{\mathrm{y}}$ values revealed significant spatial variability, which suggests strong heterogeneity of the hard-rock aquifer system. Overall, the findings of this
\end{abstract}

Deepesh Machiwal

dmachiwal@rediffmail.com

1 SWE Department, College of Technology and Engineering, MPUAT, Udaipur 313 001, India

2 Present Address: ICAR-Central Arid Zone Research Institute, Regional Research Station, Bhuj, Gujarat 370 105, India study are useful to formulate appropriate strategies for managing water resources in the area. Also, the developed spreadsheet programs may be used to analyze the pumping test data of large-diameter wells in other hard-rock regions of the world.

Keywords GIS · Groundwater recharge · Large-diameter well $\cdot$ Pumping test $\cdot$ Water table fluctuation

\section{Introduction}

Estimating hydraulic characteristics (transmissivity and storage coefficient or specific yield) of aquifer systems is an essential part of groundwater studies. The most effective, reliable and standard way of determining these characteristics is to conduct and analyze hydraulic tests such as pumping test. When the pumping tests are performed in small-diameter wells, several methods are available for analyzing the pumping test data (Theis 1935; Cooper and Jacob 1946; Neuman 1974; Hantush 1964) depending upon the type of aquifer. These methods are based on one of the assumptions that pumping test is performed in small-diameter well for which storage can be neglected. However, the pumping tests in the hard-rock subsurface formations are generally conducted in large-diameter wells where the pumped water initially comes from the well storage. The contribution of storage gradually decreases with the advancement of pumping time, and water starts to move from aquifer to well. At later stages of time, almost entire pumped water is supplied from the aquifer (Rushton 2003).

The storage contribution is worth considering while analyzing the pumping test data of the large-diameter wells (e.g., Hantush 1964; Papadopulos and Cooper 1967; Patel and Mishra 1983; Singh 2000; Çimen 2001; Balkhair 
2002). In hard-rock and fractured aquifer systems, few specific methods to determine aquifer parameters have also been suggested (e.g., Boulton and Streltsova 1977; Gringarten and Witherspoon 1972; Warren and Root 1963; Barker 1988). However, these methods require proper knowledge about the geometry of the fractures/fissures, which is often lacking, and hence, these methods could not find wide applications. It is inferred from the literature that the Papadopulos and Cooper method is the only appropriate and recommended method for analyzing pumping tests data of large-diameter wells (de Marsily 1986; Charbeneau 2000; Renard 2005), and is also widely used worldwide (Narasimhan 1968; Rushton and Holt 1981; Sakthivadivel and Rushton 1989; Ratez and Brenčič 2005). At present, several softwares are available for analyzing the pumping test data, but most of them do not contain a method for analyzing the time-drawdown data of the large-diameter wells.

Furthermore, groundwater recharge is one of the most difficult hydrologic parameters to be accurately quantified in the semi-arid and arid regions (Cherkauer 2004; Bhuiyan et al. 2009; Risser et al. 2009). Among the different recharge estimation methods, water table fluctuation (WTF) technique is the widely applied method for quantifying recharge rates (Healy and Cook 2002). Also, several researchers have emphasized the importance of exploring spatial and temporal distribution of recharge (e.g., Allison 1988; Edmunds and Gaye 1994; Robins 1998; Harrington et al. 2002; Scanlon et al. 2002). The distribution of the recharge can be successfully obtained by integrating the recharge estimation method with geographical information system (GIS) (Sophocleous 1992; Fayer et al. 1996; Civita and De Maio 2001).

The hard-rock terrain of Ahar River catchment (study area) situated in Aravalli hill range of Rajasthan, India suffered from severe drought for continuous 6 years (1999-2005), and accordingly, the groundwater levels declined significantly (Machiwal et al. 2012). Generally, the depleted groundwater levels temporarily recover up to certain extent from rainy-season recharge. However, the actual recharge of the aquifer systems could not be assessed due to lack of knowledge about the aquifer parameters. To date, systematic studies conducted in India to find out parameters of the hard-rock aquifer systems are rare, e.g. Machiwal and Jha 2015. Therefore, this study, which is first of its kind in the study area, aims at determining the aquifer parameters by analyzing pumping tests' data of large-diameter wells and estimating recharge distribution using GIS. This study involves the development of spreadsheet programs to analyze pumping test data using the Papadopulos and Cooper method.

\section{Materials and methods}

\section{Study area and surface water resources}

The Ahar River catchment is situated in Aravalli hills of Udaipur district, Rajasthan, India (Fig. 1). The catchment is bounded by longitude $73^{\circ} 36^{\prime} 51^{\prime \prime}$ to $73^{\circ} 49^{\prime} 46^{\prime \prime} \mathrm{E}$ and latitude $24^{\circ} 28^{\prime} 49^{\prime \prime}$ to $24^{\circ} 42^{\prime} 56^{\prime \prime} \mathrm{N}$ encompassing an area of about $348 \mathrm{~km}^{2}$. The area is characterized by subtropical and sub-humid to semi-arid climatic conditions. The area experiences hot summers (temperature ranging from 35 to $40{ }^{\circ} \mathrm{C}$ ), cold winters (with $10-15{ }^{\circ} \mathrm{C}$ temperature) and a distinctively defined monsoon season from mid-June to September. The average annual rainfall is $60.90 \mathrm{~cm}$ for 1971-2007 period, $90 \%$ of which is experienced during the monsoon season. The study area consists of a girdle of hills with a topographic slope from northwest to southeast direction (Fig. 1).

The source of surface water resources in the area are rivers and lakes. The Ahar River is the main river, and the other two major rivers are Kotra and Amarjok Rivers; all major rivers are seasonal. The area is drained by the Ahar River, which enters the catchment from the northeast and flows toward the southeast. The major lakes are Fatehsagar, Pichhola, Udaisagar, Lakhawali, Roopsagar and Goverdhansagar. The lakes are artificial, and their storage capacity is mostly filled up by the runoff water drained from the surrounding catchments. Hence, the water level of the lakes fluctuates greatly, and often, the lakes dry up entirely during drought seasons.

\section{Geomorphology, geology and hydrogeology}

Geomorphology consists of deep and shallow buried pediment, inselberg, residual hill and structural hill (Fig. 2). A large part of the area $\left(196 \mathrm{~km}^{2}\right.$ or $\left.56 \%\right)$ is covered with shallow buried pediment, which is present everywhere in the catchment except along the boundaries. It has moderate to good potential for groundwater occurrence (Machiwal et al. 2015). About $18 \%\left(64.28 \mathrm{~km}^{2}\right)$ area is under deep buried pediment, while residual hills encompass $6.2 \mathrm{~km}^{2}$ $(1.78 \%)$ area. The structural hills occupy $80.1 \mathrm{~km}^{2}(23 \%)$ area, which forms runoff zones and barriers for groundwater movement. The maximum proportion of the structural hills is lying along the boundaries. It has no significant recharge potential (Machiwal and Singh 2015).

Geology of the study area is composed of granite, gneiss, schist, phyllite-schist and combination of these rock formations (Machiwal et al. 2011a). Gneiss formation represents gray to dark-colored medium to coarse-grained rocks, and comprises porphyritic gneissic complex associated with aplite, amphibolite, schist and augen gneiss. 


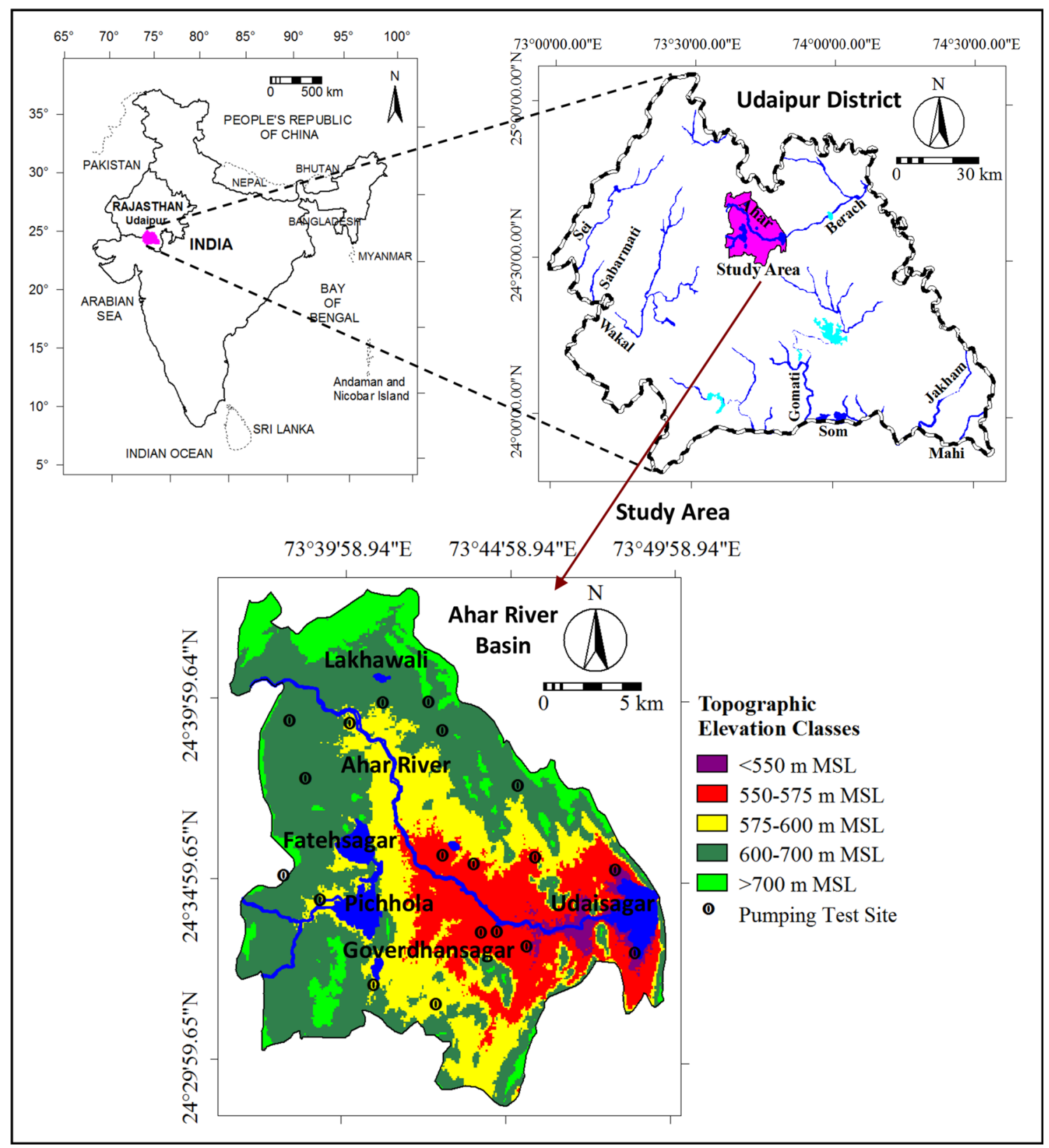

Fig. 1 Location map of study area along with pumping test sites

Schist litho units are basically compact, hard and fine- to medium-grained, which are characterized by alternating bands of light- and dark-colored ferromagnesian minerals. Phyllite-schist rocky formations represent argillaceous sediments and grades from shale, slate, phyllite to micaschist, which are soft and friable (Machiwal and Singh 2015).

Aquifers, characterized by the upper weathered strata of the hard-rocks, contain the groundwater at shallow depths and mainly under unconfined conditions (Machiwal et al. 2011b). The mean groundwater depth varies from 2 to
$23 \mathrm{~m}$ below ground surface (bgs) in pre-monsoon to 2-14 m bgs in post-monsoon season (Machiwal and Singh 2015). The aquifers have very little primary porosity, and the groundwater movement is mainly controlled by the secondary porosity in the form of joints, faults and fissures. Of the total groundwater-extracting mechanisms in the area, dug wells account for $68.52 \%$, tube wells for $1.62 \%$, handpumps for $29.35 \%$ and step wells for $0.51 \%$ (Singh 2002). The well density is relatively higher in the southeast part, while the northeast and central parts have lower well density (Singh 2002). 


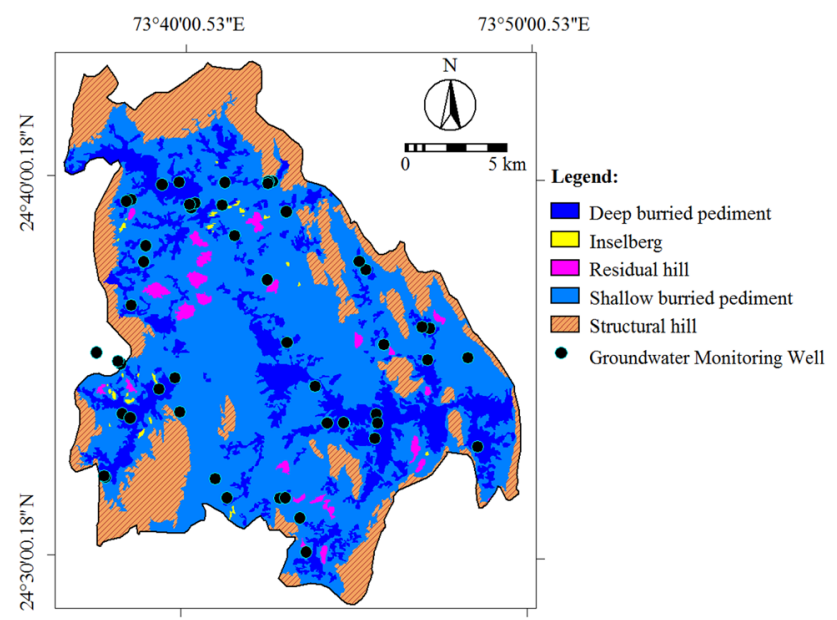

Fig. 2 Geomorphology map along with groundwater monitoring wells

\section{Data collection and database creation in geographic information system}

The boundaries of Ahar River catchment were demarcated based on watershed approach from geographically registered toposheets (i.e., $45 \mathrm{H} / 9,45 \mathrm{H} / 10,45 \mathrm{H} / 11,45 \mathrm{H} / 14$, and $45 \mathrm{H} / 15$ ) acquired from the Survey of India. This study utilized GIS for the preparation and processing of maps of aquifer parameters, groundwater levels and recharge through geostatistical modeling using Integrated Land and Water Information System (ILWIS) software, version 3.2 (ILWIS 2001). The coordinate system was developed with Universal Transverse Mercator as projection system, Everest India 1956 as Ellipsoid and Indian (India Nepal) as Datum. The extracted map of the Ahar River catchment along with its location is shown in Fig. 1.

This study involves conducting pumping tests at 19 sites (Fig. 1) and monitoring of the monthly as well as pre- and post-monsoon groundwater levels at 50 sites (Fig. 2) over 3-year period (2006-2008). The groundwater levels were recorded up to the nearest 1-mm accuracy by means of TLC (temperature level conductivity) Meter made by Solinst, Canada. The latitude and longitude of the groundwater monitoring and pumping test sites were recorded by means of Trimble-made Global Positioning System. During summers, long-duration pumping (more than 4-5 h) could not be sustained from the dug wells, and therefore, the tests were mostly conducted during postrainy season when the groundwater levels were at shallow depths.

\section{Exploring the effect of rainfall on groundwater level}

This study explored the effect of the rainfall occurrence on the groundwater level fluctuation by plotting bar charts of the rainfall along with mean groundwater levels. There is only one rainfall gauging station in the area, and therefore, the relationship between rainfall and recharge could not be evaluated at spatial scale.

\section{Checking normality of groundwater levels}

The basic pre-requisite condition prior to using the groundwater level data for geostatistical modeling is that the data should follow normal distribution. To check and confirm presence of normality in the pre- and post-monsoon groundwater levels, histograms were plotted and Shapiro-Wilk test was applied. All the statistical analyses were performed using STATISTICA software.

\section{Interpolating groundwater levels by geostatistical modeling and GIS technique}

The values of the pre- and post-monsoon groundwater levels were plotted in GIS to prepare point maps, which were subsequently space-interpolated using GIS-based Kriging technique. Four geostatistical models namely, spherical, circular, Gaussian, and exponential, were fitted to the experimental variograms of the pre- and post-monsoon groundwater levels of 3 years (2006-2008). Then, the best-fit model was used for the spatial interpolation of the groundwater levels. The raster maps of the pre- and postmonsoon groundwater levels $\left(\mathrm{GWL}_{\text {pre }}\right.$ and $\left.\mathrm{GWL}_{\text {post }}\right)$ were differenced for individual 3 years to generate groundwater fluctuation $\left(\Delta \mathrm{GW}_{\text {monsoon }}\right)$ maps in GIS as follows:

$\Delta \mathrm{GW}_{\text {monsoon }}=\mathrm{GWL}_{\text {pre }}-\mathrm{GWL}_{\text {post }}$.

\section{Conducting pumping tests in large-diameter dug wells}

In the study area, abundant large-diameter dug wells are available to extract the groundwater. A total of 19 largediameter wells were selected to perform pumping tests; the location of the test sites is shown in Fig. 1. The pumping rate during the individual tests was kept constant, which was measured by volumetric method. A cylindrical-shaped container of known volume was filled up from the water coming out of the pumping well and the time taken was recorded. The discharge was measured at regular time interval to control variability of the discharge. Shape of the pumping wells was rectangular, and therefore, an equivalent diameter of the circular well was used for computations. The length, width and depth of the pumping well along with initial water level were recorded before start of the every test. With the start of the test, drawdown at different time intervals was measured in the pumping well using the TLC Meter. The time interval for recording the 
drawdown was increased with the progress of the test. Salient details of the pumping wells are provided in Table 1. The pumping test data were analyzed using the Papadopulos and Cooper method, which is briefly described below.

\section{Papadopulos and Cooper method}

The geometry of large-diameter wells in a confined aquifer is shown in Fig. 3. Papadopulos and Cooper developed an analytical solution and type curves in and around a largediameter well in a homogeneous and isotropic non-leaky confined aquifer. They took into consideration the water derived from storage within the well and assumed a horizontal aquifer with a constant thickness and a constant discharge for a fully penetrating well.

The governing second-order partial differential equation is:

$\frac{\partial^{2} s}{\partial r^{2}}+\frac{1}{r} \frac{\partial s}{\partial r}=\frac{S}{T} \frac{\partial s}{\partial t} \quad r \geq r_{\mathrm{w}}$,

where $s$ is the drawdown in the aquifer at a distance $r$ at time $t ; S$ is the storage coefficient of the aquifer; $T$ is the transmissivity; and $r_{\mathrm{w}}$ is the effective radius of well screen.

The initial conditions are:

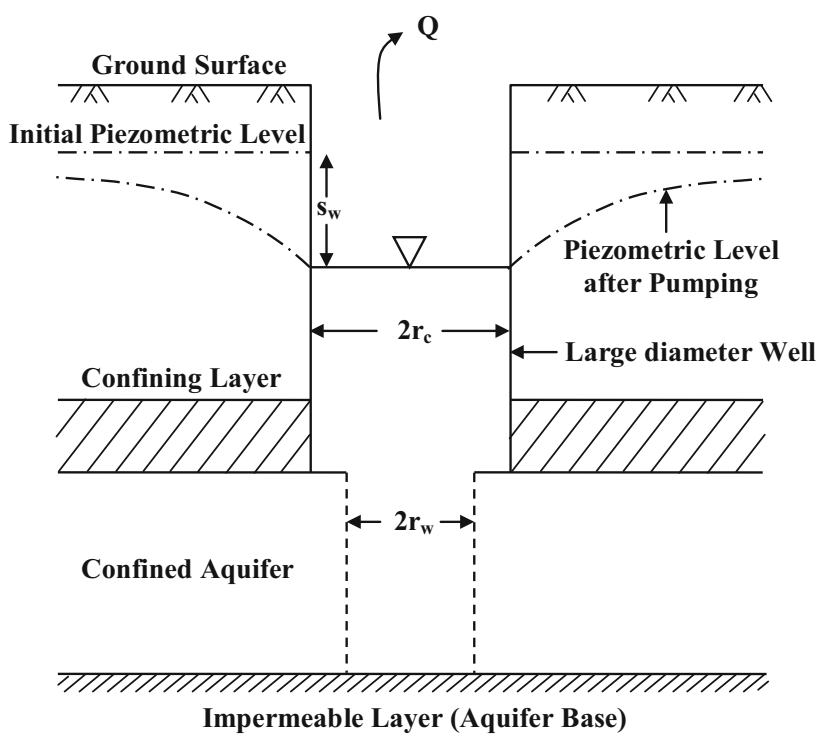

Fig. 3 Ideal large-diameter well in a confined aquifer. Source: Papadopulos and Cooper (1967)

$s(r, 0)=0 \quad r \geq r_{\mathrm{w}}$,

$s_{\mathrm{w}}(0)=0$,

and the boundary conditions are:

Table 1 Salient details of the pumping wells

\begin{tabular}{|c|c|c|c|c|c|c|}
\hline \multirow[t]{2}{*}{ S. no. } & \multirow[t]{2}{*}{ Site } & \multicolumn{3}{|c|}{ Dimensions of pumping well } & \multirow[t]{2}{*}{ Pumping rate $\left(\mathrm{m}^{3} /\right.$ day $)$} & \multirow[t]{2}{*}{ Test duration (min) } \\
\hline & & Length $(\mathrm{m})$ & Width (m) & Depth (m) & & \\
\hline 1 & Farm Pond, CTAE & 3.4 & 3.2 & 20.19 & 360 & 470 \\
\hline 2 & Manpura, Lakhawali & 4.0 & 2.5 & 18.34 & 654 & 420 \\
\hline 3 & Brahmnon Ka Guda & 3.0 & 1.5 & 17.11 & 560 & 480 \\
\hline 4 & Kaladwas & 3.0 & 1.7 & 16.47 & 174 & 274 \\
\hline 5 & Rehta, Debari & 5.6 & 2.7 & 15.97 & 516 & 355 \\
\hline 6 & Lakarwas & 3.2 & 2.5 & 12.91 & 580 & 485 \\
\hline 7 & Bedwas & 3.2 & 1.9 & 26.79 & 192 & 480 \\
\hline 8 & Kushalbagh & 4.7 & 2.1 & 20.10 & 503 & 410 \\
\hline 9 & Gorela, Udaipur & 4.0 & 3.0 & 22.30 & 588 & 405 \\
\hline 10 & Dheenkli & 7.5 & 5.35 & 22.65 & 579 & 391 \\
\hline 11 & Eklingpura & 4.0 & 2.5 & 21.70 & 631 & 372 \\
\hline 12 & Pheniyon Ka Guda & 6.0 & 4.8 & 30.90 & 449 & 399 \\
\hline 13 & Dakan Kotra & 5.5 & 3.2 & 29.30 & 372 & 419 \\
\hline 14 & Bhilon Ka Bedla & 4.3 & 4.0 & 17.70 & 639 & 296 \\
\hline 15 & Seesarma & 6.7 & 2.9 & 16.90 & 475 & 345 \\
\hline 16 & Liyon Ka Guda & 5.5 & 4.0 & 20.45 & 536 & 329 \\
\hline 17 & Chikalwas & 4.2 & 2.6 & 26.60 & 5517 & 376 \\
\hline 18 & Baleecha, Goverdhan Vilas & 4.4 & 3.0 & 13.275 & 276 & 280 \\
\hline 19 & Eklingpura, Manwakhera & 3.4 & 1.9 & 19.15 & 406 & 300 \\
\hline
\end{tabular}


$s_{\mathrm{W}}\left(r_{\mathrm{W}}, t\right)=s_{\mathrm{W}}(t)$,

$s(\infty, t)=0$,

$2 \pi r_{\mathrm{w}} T \frac{\partial s\left(r_{\mathrm{w}}, t\right)}{\partial t}-\pi r_{\mathrm{c}}^{2} \frac{\partial s_{\mathrm{w}}(t)}{\partial t}=-Q \quad t \geq 0$

where $s_{\mathrm{w}}(t)$ is the drawdown in the well at time $t$ and $r_{\mathrm{c}}$ is the radius of the well casing in the interval over which the water level declines.

With the initial and boundary conditions stated above, Eq. (2) was solved using the Laplace transform method, and the following solution was obtained (Papadopulos and Cooper 1967; Papadopulos 1967; Reed 1980):

$s(r, t)=\frac{Q}{4 \pi T} F(u, \alpha, \rho)$

where

$F(u, \alpha, \rho)=\frac{8 \alpha}{\pi} \int_{0}^{\infty} \frac{C(\beta)}{D(\beta) \beta^{2}} \partial \beta$,

and

$C(\beta)=\left[1-\exp \left(-\beta^{2} \frac{\rho^{2}}{4 u}\right)\right]\left[J_{0}(\beta \rho) A(\beta)-Y_{0}(\beta \rho) B(\beta)\right]$,

where

$A(\beta)=\beta Y_{0}(\beta)-2 \alpha Y_{1}(\beta)$,

$B(\beta)=\beta J_{0}(\beta)-2 \alpha J_{1}(\beta)^{2}$,

$D(\beta)=[A(\beta)]^{2}+[B(\beta)]^{2}$,

$u=\frac{r^{2} S}{4 T t}$

$\alpha=\frac{r_{\mathrm{w}}^{2} S}{r_{\mathrm{c}}^{2}}$

$\rho=\frac{r}{r_{\mathrm{w}}}$

where $J_{0}$ (and $Y_{0}$ ), and $Y_{1}$ represent zero-order and firstorder Bessel functions of the first and second kind, respectively.

Solution of governing equation in terms of drawdown inside the pumped well is obtained at $r=r_{\mathrm{w}}$ and expressed as:

$s_{\mathrm{w}}(t)=\frac{Q}{4 \pi T} F(u, \alpha, \rho)$,

where

$F\left(u_{\mathrm{w}}, \alpha\right)=F(u, \alpha, 1)$

and

$u_{\mathrm{w}}=\frac{r_{\mathrm{w}}^{2} S}{4 T t}$, where $s_{\mathrm{w}}(t)$ is the drawdown in the well at time $t(\mathrm{~m}) ; r_{\mathrm{c}}$ is the radius of the well casing in the interval over which the water level declines (m); $S$ is the storage coefficient of the aquifer; $T$ is the transmissivity $\left(\mathrm{m}^{2} /\right.$ day); and $r_{\mathrm{w}}$ is the effective radius of well screen $(\mathrm{m})$.

\section{Matching of observed time-drawdown curve with theoretical type curve}

Papadopulos and Cooper (1967) generated a family of type curves of $s_{\mathrm{w}} / \frac{Q}{4 \pi T}$ versus $\frac{1}{u_{\mathrm{w}}}$ with one curve for each $\alpha$. Aquifer parameters were determined by fitting observed time-drawdown data to one of the type curves and selecting a match point. For the chosen match point, four parameters (two from each axis of both observed timedrawdown curve and type curve) are read, and the aquifer parameters were computed using Eqs. (17) and (14).

The measured drawdowns of the unconfined aquifer were converted into the equivalent drawdowns of confined aquifer using the following transformation (Jacob 1944).

$S_{\mathrm{c}}=s_{\mathrm{uc}}-\frac{s_{\mathrm{uc}}^{2}}{2 m}$

where $S_{\mathrm{c}}$ is the equivalent drawdown in a non-leaky confined aquifer $(\mathrm{m}) ; s_{\mathrm{uc}}$ is the drawdown observed in an unconfined aquifer $(\mathrm{m})$; and $m$ is the initial saturated thickness of the aquifer $(\mathrm{m})$.

The initial saturated thickness was obtained by adding average depth of impervious layer below the bottom of the well $\left(D_{\mathrm{IL}}\right)$ to water column depth $\left(D_{\mathrm{wc}}\right)$ in the pumping well before start of the test. The average depth of impervious layer was computed from the following equation (Jat 1990).

$D_{\mathrm{IL}}=\frac{K_{\mathrm{h}}}{K_{\mathrm{v}}} \times D_{\mathrm{wc}}$,

where $K_{\mathrm{h}}$ is the horizontal hydraulic conductivity (m/day) and $K_{\mathrm{v}}$ is the vertical hydraulic conductivity (m/day). The ratio $K_{\mathrm{h}} / K_{\mathrm{v}}$ was found to be 2.2 for the study area (Jat 1990).

Furthermore, partial penetration correction was applied using the following expression as suggested by Hantush (1964).

$S_{\mathrm{fc}}=S_{\mathrm{c}}-\frac{S_{\mathrm{c}}^{2}}{2 L}$

where $S_{\mathrm{fc}}$ is the equivalent fully penetrating well drawdown in a confined aquifer $(\mathrm{m})$ and $L$ is the penetration depth of the pumped well $(\mathrm{m})$. 


\section{Preparing spatial distribution maps of aquifer parameters}

The aquifer transmissivity and specific yield values were used to prepare GIS-based point maps using ILWIS software. The point maps were then spatially interpolated by adopting moving average inverse distance weighted technique. The obtained spatial raster maps were sliced into suitable classes of the parameter values. The number of classes and range of each class for both the individual parameters were chosen by observing the corresponding histograms of pixel values.

\section{Computing GIS-coupled net groundwater recharge}

In the study area, the groundwater extraction during rainy season is negligible for domestic and irrigation purposes, because, mostly, surface water is used to meet the drinking water requirements and farmers generally grow rainfed crops during the rainy season. In the absence of any groundwater withdrawals, it may safely be assumed that the groundwater levels fluctuate (or rise) only due to recharge of rainwater. Under such conditions, net groundwater recharge can be estimated using water table fluctuation (WTF) technique, which is based on the premise that the groundwater level fluctuation occurs due to recharge water arriving at the water table (Healy and Cook 2002). The WTF technique is best applied to shallow water tables that display sharp water-level rises and declines (Healy and Cook 2002; Scanlon et al. 2002). The net groundwater recharge (GWR) was calculated as (Healy and Cook 2002):

$\mathrm{GWR}=S_{\mathrm{y}} \times \Delta \mathrm{GW}_{\text {monsoon }}$,

where $S_{\mathrm{y}}$ is the specific yield.

In this study, GIS-based raster maps of the groundwater fluctuation and specific yield were used for computing the groundwater recharge coupled with GIS technique for 3 years (2006-2008). The GIS facilitated the computation of net recharge on pixel-by-pixel basis. The raster maps of the groundwater recharge were sliced into suitable classes selected by observing histogram of the recharge values for all pixels.

\section{Results and discussion}

\section{Relationship between rainfall and groundwater levels}

The bar charts of the monthly rainfall along with spatially averaged groundwater levels were plotted for May 2006July 2009 period, and the same is depicted in Fig. 4. It is

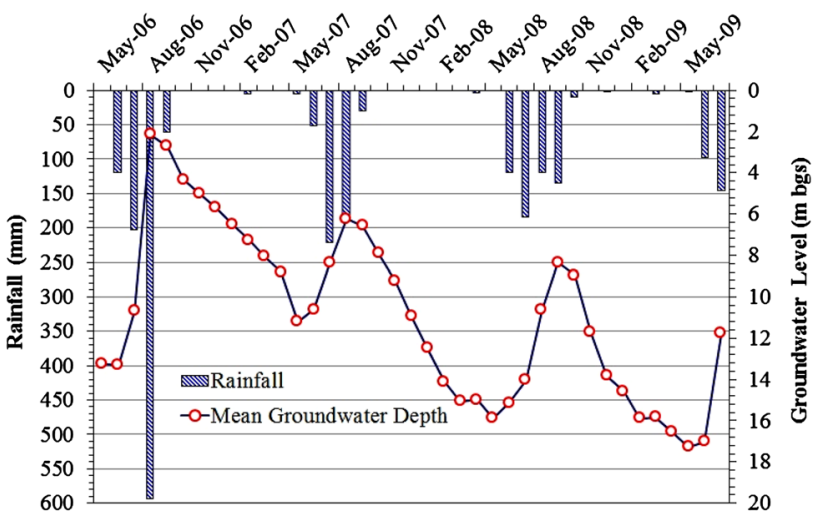

Fig. 4 Bar charts of monthly rainfall and spatially averaged groundwater level below ground surface (bgs)

clearly seen that the groundwater levels showed peaks during the monsoon season when the rainfall occurs. The maximum recharge to the shallow aquifer system from the surface in a year is contributed during the monsoon season. In addition, it is also observed that the groundwater levels were at the deepest levels before start of monsoon season. Between peaks and troughs, the mean groundwater level shows a continuous decline in effect of their withdrawal for drinking, irrigation and industrial purposes in the area. Thus, the groundwater levels are fairly related to the rainfall.

\section{Normality of the groundwater levels}

Histograms along with computed Shapiro-Wilk (S-W) test-statistics of the pre- and post-monsoon groundwater levels for period 2006-2008 are presented in Fig. 5a-f. It is apparent from Fig. 5a, e, f that the shape of the histograms approximately resembles a normal distribution curve for the pre-monsoon 2006, and pre- and postmonsoon 2008. The presence of normality in the groundwater levels during three seasons is further confirmed from the results of the S-W test at $1 \%$ significance level. The computed S-W test-statistics indicate that null hypothesis of existence of the normality cannot be rejected ( $p$ value $>0.01$ ) for pre-monsoon seasons of years 2006 and 2008, and post-monsoon season of 2008 . On the contrary, the groundwater levels of post-monsoon season of year 2006 and pre- and post-monsoon season of year 2007 do not follow the normal distribution as depicted from the shapes of the histograms shown in Fig. 5b-d. The non-normality of the groundwater levels is also verified from the computed $\mathrm{S}-\mathrm{W}$ test-statistics ( $p$ value $<0.01)$ at $1 \%$ significance level.

Hence, the groundwater level data for the three seasons lack the normality requirement, which is essential prior to geostatistical analysis. Therefore, the non-normal 

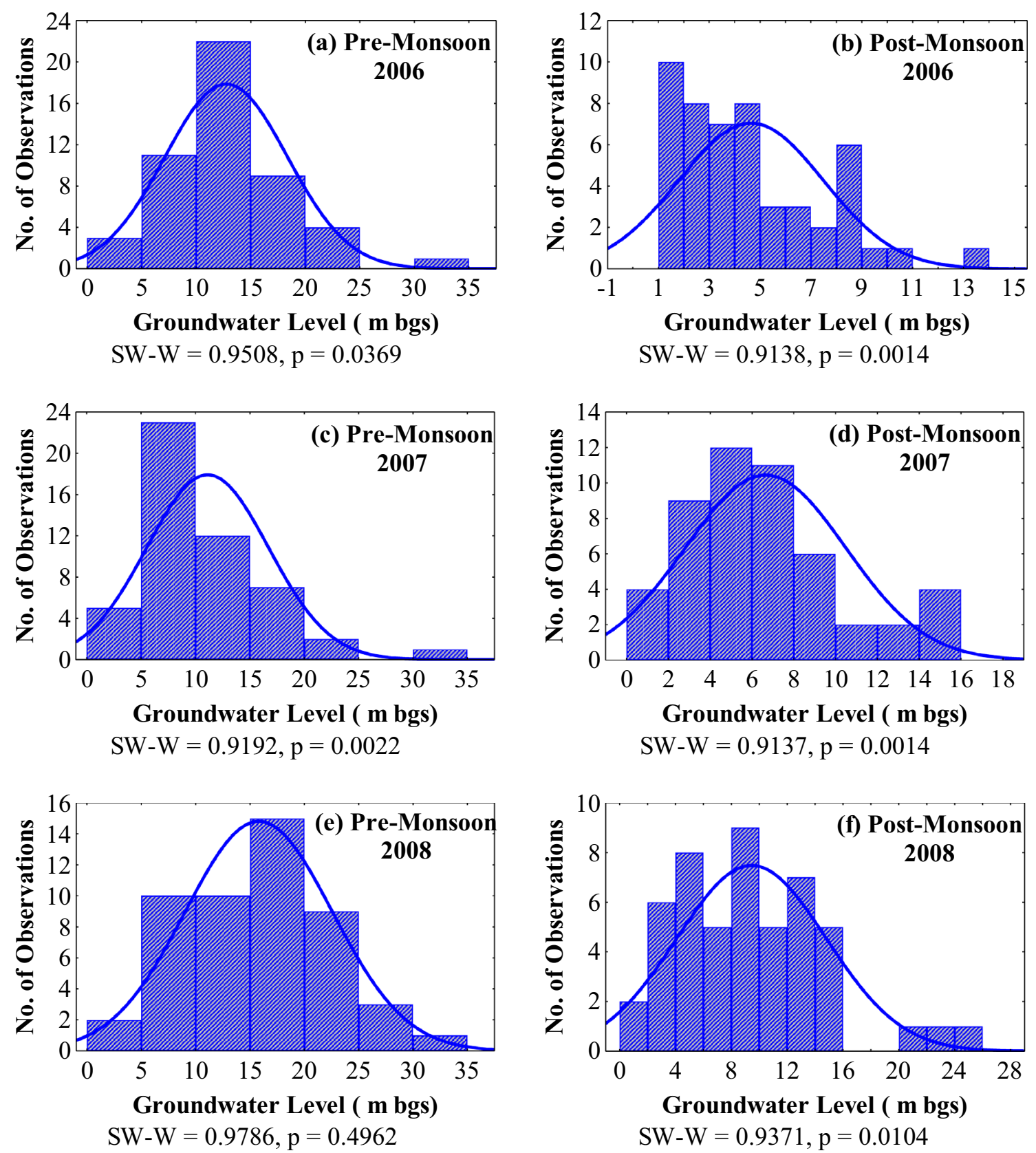

Fig. 5 Histograms and Shapiro-Wilk test-statistics of pre- and post-monsoon groundwater levels for 3 years

groundwater levels were first subjected to logarithmic transformation. The histograms of the logarithmically transformed groundwater levels followed the shape of normal curve, and the results were confirmed from the computed S-W test-statistics ( $p$ value $>0.01$ ) (Fig. 6a-c). Thus, the log-transformed groundwater levels for the premonsoon season of year 2007 and post-monsoon season of years 2006 and 2007 along with the original pre- and postmonsoon groundwater level data for rest of the seasons were subsequently subjected to the geostatistical modeling tool for the GIS-based spatial interpolation.

\section{Behavior and fluctuation of groundwater levels}

Three geostatistical models, i.e., spherical, circular and exponential were found to be the best-fit models for interpolating the monthly groundwater levels in the study area (Machiwal et al. 2012). However, the exponential model was selected as the best-fit model in this study for computing spatial distribution of the pre- and post-monsoon groundwater levels. Parameters of the best-fit geostatistical model are presented in Table 2. The nugget value for the best-fit model shows that variance at zero lag 
Fig. 6 Histograms and Shapiro-Wilk test-statistics of log-transformed pre- and postmonsoon groundwater levels for (a) post-monsoon 2006, (b) premonsoon 2007 and (c) postmonsoon 2007
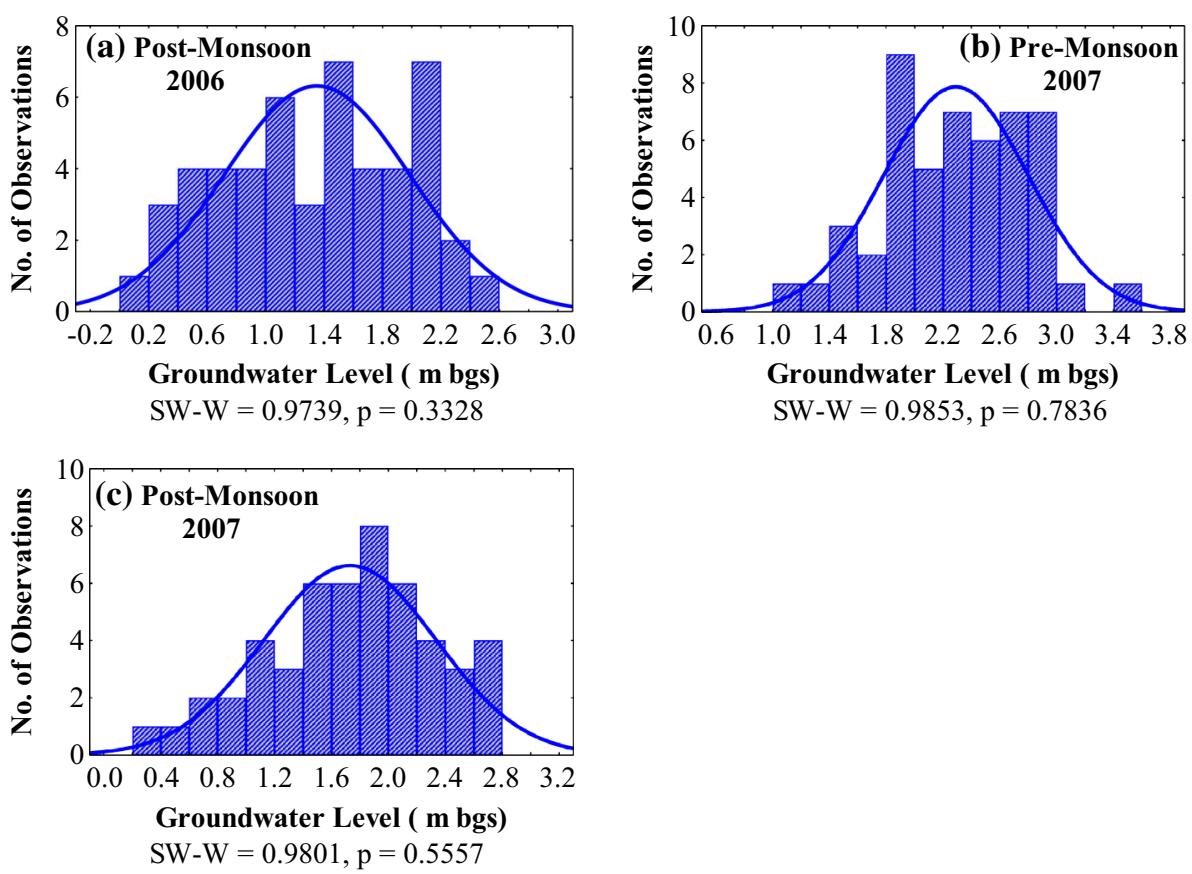

Table 2 Parameters of the best-fitted geostatistical model for preand post-monsoon groundwater levels

\begin{tabular}{lllll}
\hline Year & Season & Nugget $\left(\mathrm{m}^{2}\right)$ & Sill $\left(\mathrm{m}^{2}\right)$ & Range $(\mathrm{m})$ \\
\hline 2006 & Pre-monsoon & 2 & 40 & 3500 \\
& Post-monsoon & 0.2 & 0.4 & 3500 \\
2007 & Pre-monsoon & 0.02 & 0.27 & 2000 \\
& Post-monsoon & 0.03 & 0.37 & 1700 \\
2008 & Pre-monsoon & 2 & 55 & 2500 \\
& Post-monsoon & 4 & 28 & 3500 \\
\hline
\end{tabular}

distance ranges from 0.02 to $4 \mathrm{~m}^{2}$ (Table 2). The nugget value other than zero indicates either measurement errors or spatial variability of the groundwater levels at smallscale even over small distances (Delhomme 1978). It is also revealed from Table 2 that the range parameter varies from 1.7 to $3.5 \mathrm{~km}$ during pre- and post-monsoon seasons, which indicates that the groundwater levels are autocorrelated up to $3.5 \mathrm{~km}$ separation distance in the area. The bestfit exponential model variograms for the pre- and postmonsoon seasons are shown in Fig. 7a-f. The raster maps of the groundwater levels were generated using the best-fit model for the pre- and post-monsoon seasons of 3 years (2006-2008), and the classified contour maps of the kriged groundwater levels are shown in Fig. 8a-f. The generated raster maps of the log-transformed groundwater levels were back-transformed to enable us to estimate the groundwater level distribution at the original scale.

Figure 8a-f depicts that the groundwater is relatively shallow (within $8-11 \mathrm{~m}$ during pre-monsoon and 2-5 $\mathrm{m}$ during post-monsoon) in central part of the study area. During both the seasons, the groundwater is relatively deep near the boundary of the area where the topographic elevations are relatively high (Fig. 1) and mostly structural hills are present (Fig. 2). Figure 8 reveals large spatial variation of the groundwater levels during pre-monsoon in comparison to that during post-monsoon season. Relatively less variation during post-monsoon season is due to low specific yield of the underlying hard-rock aquifer system, which permits the water levels to rise rapidly in response to rainy-season recharge. In general, the post-monsoon groundwater levels are easily augmented up to $2-5 \mathrm{~m}$ below ground surface (bgs) in response to regular recharge events, and the groundwater level remains steady in almost entire area due to absence of pumping at start of the postmonsoon season. It is worth mentioning that relatively large number of wells extract groundwater for irrigationpurpose in the southern and northeast portions (Singh 2002), which puts large stress on the groundwater levels. Therefore, the groundwater in the southern and eastern portions is mostly available at great depths compared to that in central parts of the area.

The fluctuation of the groundwater levels over the rainy season was computed by differencing the GIS-based raster maps of the pre- and post-monsoon groundwater levels. The resulted classified groundwater fluctuation maps for the 3 years are shown in Fig. 9a-c. It is seen from Fig. 9a$\mathrm{c}$ that the overall fluctuation of the groundwater levels is relatively less in the year 2007 compared to that in rest 2 years. In the year 2007, the groundwater fluctuation was within $6 \mathrm{~m}$ in $95.7 \%$ of the area, while only 19.2 and 

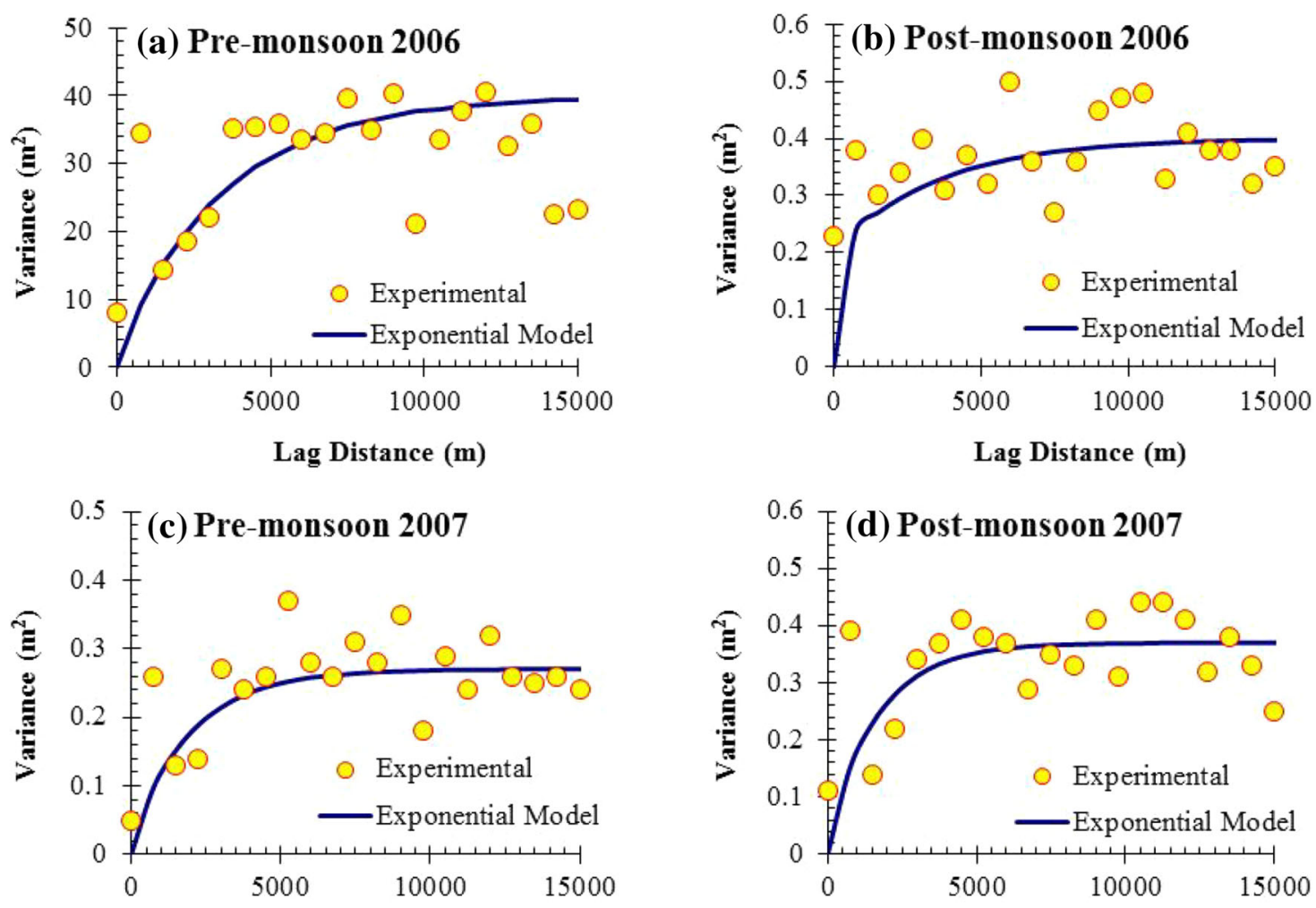

Lag Distance (m)
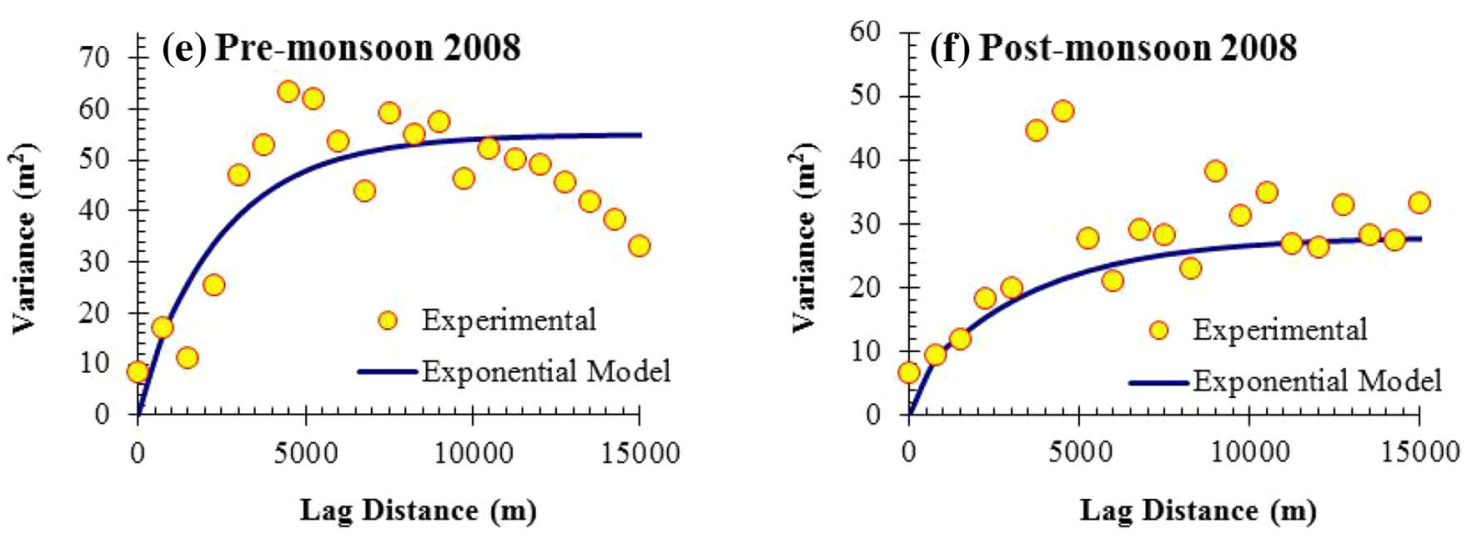

Fig. 7 Experimental and theoretical fitted variograms for pre- and post-monsoon groundwater levels

$66.2 \%$ of the area experienced $6 \mathrm{~m}$ or less fluctuation in 2006 and 2008, respectively. The less fluctuation in 2007 is attributed to relatively less rainfall $(494 \mathrm{~mm})$ in that year in comparison to high rainfall amounts of 984 and $572 \mathrm{~mm}$ in 2006 and 2008, respectively. Thus, it is evident that the groundwater fluctuation showed good response to rainfall occurrences in the area.

\section{Spatial variability of aquifer parameters}

The aquifer parameters (transmissivity and specific yield) determined for 19 sites by analyzing the pumping test data using Papadopulos-Cooper method through the developed spreadsheet programs, are given in Table 3 . The best-fit matching of both the curves for one of the sites is illustrated in Fig. 10 as an example. It is seen from Table 3 that the transmissivity ranged from 65 to $2239 \mathrm{~m}^{2} /$ day with the mean of $330 \mathrm{~m}^{2} /$ day, whereas the specific yield varied from 0.211 to $0.51 \times 10^{-5}$ with the mean value of 0.0240 for the area, which are reasonable and reliable for the type of subsurface formations present in the area (CGWB 1997). It is evident that both the aquifer parameters vary significantly over small distances. This wide variation in hydraulic parameters of the aquifer suggests strong heterogeneity, which is most likely in hard-rock subsurface formations of the study area (NABARD 2006). 
Fig. 8 Groundwater levels in study area during 2006, 2007 and 2008

(a) Pre-Monsoon Season 2006

(b) Post-Monsoon Season 2006

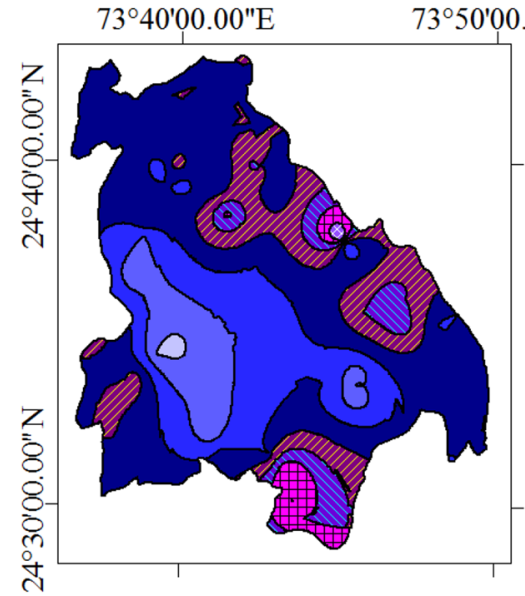

(c) Pre-Monsoon Season 2007

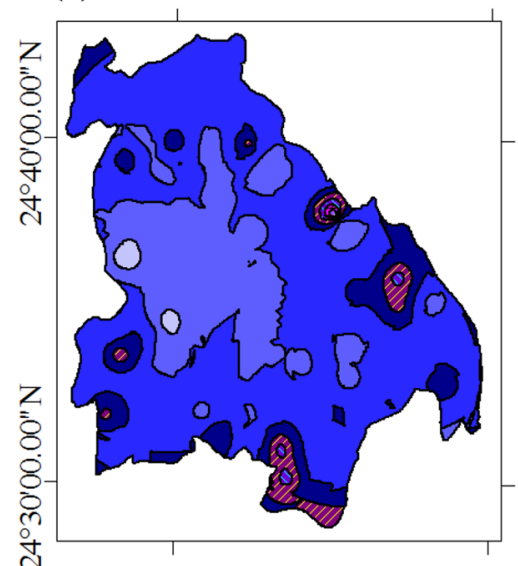

(e) Pre-Monsoon Season 2008

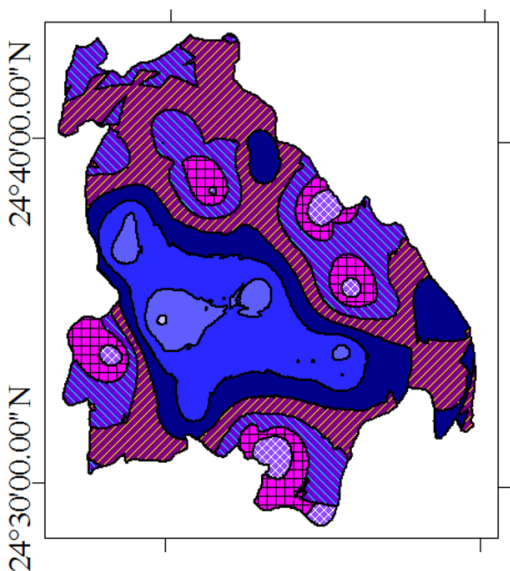

"E $73^{\circ} 40^{\prime} 00.00^{\prime \prime} \mathrm{E}$

$73^{\circ} 50^{\prime} 00.00^{\prime \prime} \mathrm{E}$

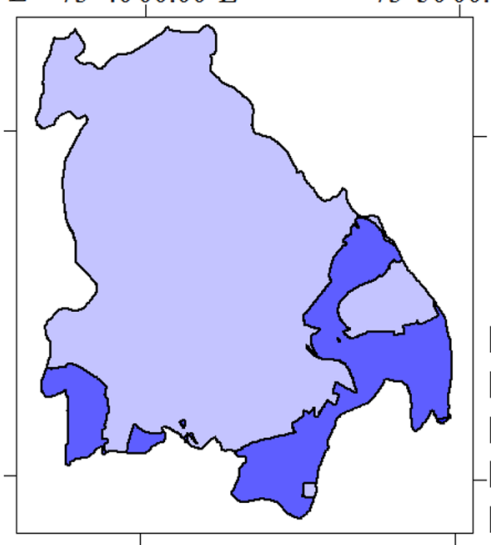

(d) Post-Monsoon Season 2007

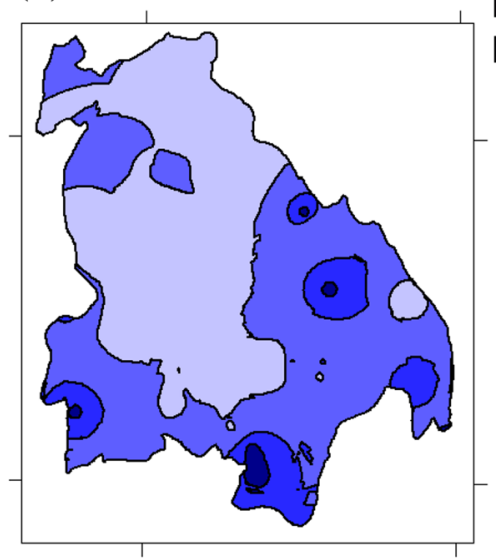

(f) Post-Monsoon Season 2008

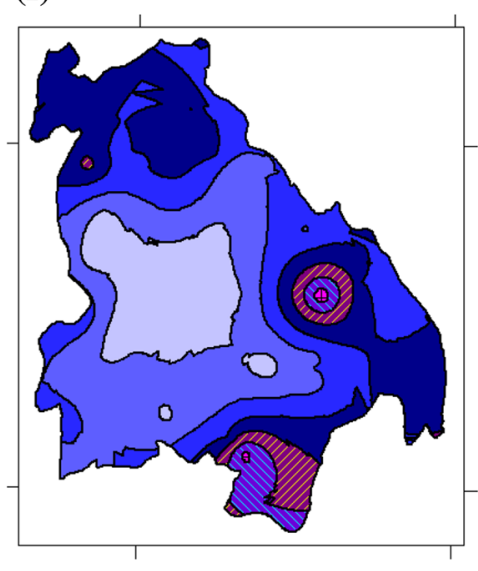

The estimated hydraulic parameters were used for computing the drawdown at different time intervals through forward modeling approach. The measured and computed drawdowns were compared to evaluate the efficacy of the developed spreadsheet programs and matching of the observed time-drawdown and type curves by employing two performance criteria: correlation coefficient $(R)$ and root mean square error (RMSE). The computed values of both the performance criteria are shown in Table 3. It is seen that the RMSE ranges between 0.017 and $0.339 \mathrm{~m}$, which may be considered satisfactory for the large-diameter pumping wells. Hence, the developed spreadsheet programs and the curve-matching are accurate enough and provide adequate results. The accuracy of the results is further verified by the significant $R$ values $(>0.95)$.

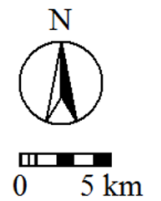

Groundwater Level Classes

$2-5 \mathrm{~m}$ bgs

$5-8 \mathrm{~m}$ bgs

8-11 m bgs

$11-14 \mathrm{~m}$ bgs

$14-17 \mathrm{~m}$ bgs

$17-20 \mathrm{~m}$ bgs

20-23 m bgs $>23 \mathrm{~m} \mathrm{bgs}$ 


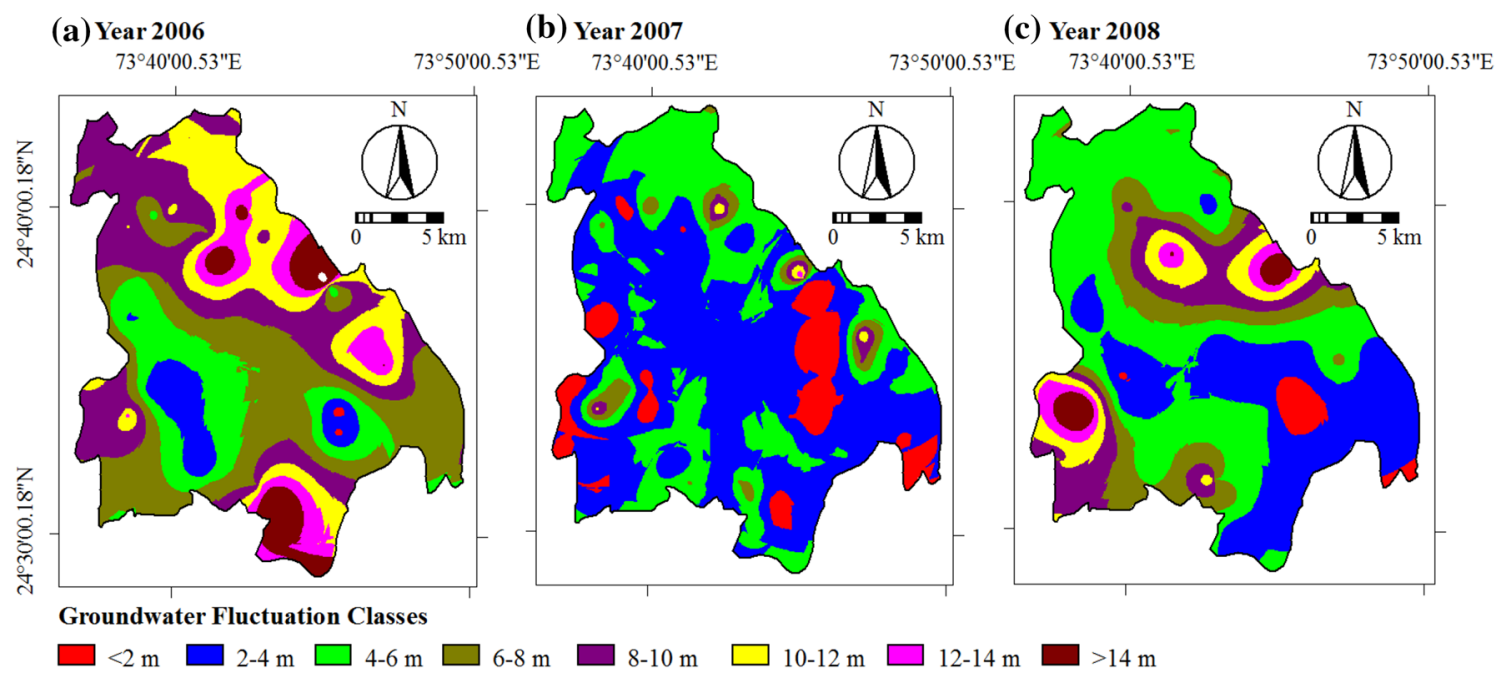

Fig. 9 Groundwater fluctuation in study area during 2006, 2007 and 2008

Table 3 Specific yield and transmissivity values for the 19 pumping test sites

\begin{tabular}{lrlll}
\hline Site & Transmissivity $\left(\mathrm{m}^{2} /\right.$ day $)$ & Specific yield & RMSE $(\mathrm{m})$ & $R$ \\
\hline 1 & 165 & 0.00298 & 0.065 & 0.995 \\
2 & 260 & 0.17 & 0.185 & 0.972 \\
3 & 655 & 0.025 & 0.030 & 0.988 \\
4 & 68 & 0.00014 & 0.040 & 0.999 \\
5 & 123 & 0.009 & 0.117 & 0.990 \\
6 & 277 & 0.0011 & 0.037 & 0.999 \\
7 & 76 & 0.0046 & 0.095 & 0.990 \\
8 & 199 & 0.00069 & 0.339 & 0.989 \\
9 & 292 & 0.00616 & 0.213 & 0.997 \\
10 & 241 & 0.00997 & 0.017 & 1.00 \\
11 & 630 & 0.0000132 & 0.031 & 0.997 \\
12 & 174 & 0.000962 & 0.055 & 1.00 \\
13 & 151 & 0.0000051 & 0.072 & 0.997 \\
14 & 158 & 0.0008 & 0.095 & 0.996 \\
15 & 159 & 0.00001 & 0.128 & 0.998 \\
16 & 201 & 0.0027 & 0.029 & 0.998 \\
17 & 2239 & 0.211 & 0.129 & 0.952 \\
18 & 65 & 0.00011 & 0.053 & 0.998 \\
19 & 129 & 0.0102 & 0.191 & 0.988 \\
\hline & & & &
\end{tabular}

The GIS-based spatial distribution of the transmissivity and specific yield values in the area is shown in Figs. 11 and 12, respectively. It is apparent from Fig. 11 that the aquifer systems have the highest values ( $>600 \mathrm{~m}^{2} /$ day) of the transmissivity in the northern portion, while the transmissivity decreases in the eastern, western and southern portions of the area. A gradient of the transmissivity can be seen in Fig. 11, which shows that the transmissivity decreases from the north toward south direction following almost the general topography of the area. Figure 11 reveals that more than half $(59.2 \%)$ of the area contains low to moderate (150-300 $\mathrm{m}^{2} /$ day) transmissivity values. The very low transmissivity $\left(70-150 \mathrm{~m}^{2} /\right.$ day) is found in few scattered patches $(0.3 \%$ of the area) in the southern portion. The high transmissivity value in the northern portion indicates that the underlying hard-rock aquifer may have large density of the fractures in the weathered strata, whereas the low transmissivity value in the southern portion may be due to presence of skeletal type of soils along with rock outcrops and existence of less secondary openings in the strata (Machiwal et al. 2015).

It is evident from Fig. 12 that the aquifer systems have the highest values $(0.08-0.25)$ of the specific yield in the northern portion where the aquifer systems are highly transmissive also. The northern portion, in fact, is likely to form the recharge zone with relatively higher topographic elevations ranging from 575 to $700 \mathrm{~m}$ MSL (Fig. 1). A gradient of the specific yield, similar to transmissivity, can be discerned showing a decrease in the specific yield from the north toward south direction (Fig. 12) following more or less the topography of the area. The possible causes of the high value of the specific yield in northern portion and the low value in the southern portion are most likely linked with the geometry of the fractures, i.e., density, length and openings. It is also important to note that the specific yield exhibits significant spatial variations from one location to another in most hydrogeological settings (Machiwal and Jha 2015). The wide variation in the specific yield values suggests heterogeneity, which is a common feature of the hard-rock subsurface formations (NABARD 2006). Moreover, Fig. 12 reveals that the major portion $(42.6 \%)$ of the area contains low to moderate $(0.01-0.03)$ specific yield values, and this portion also closely matches with the portion having low to moderate transmissivity values. The 


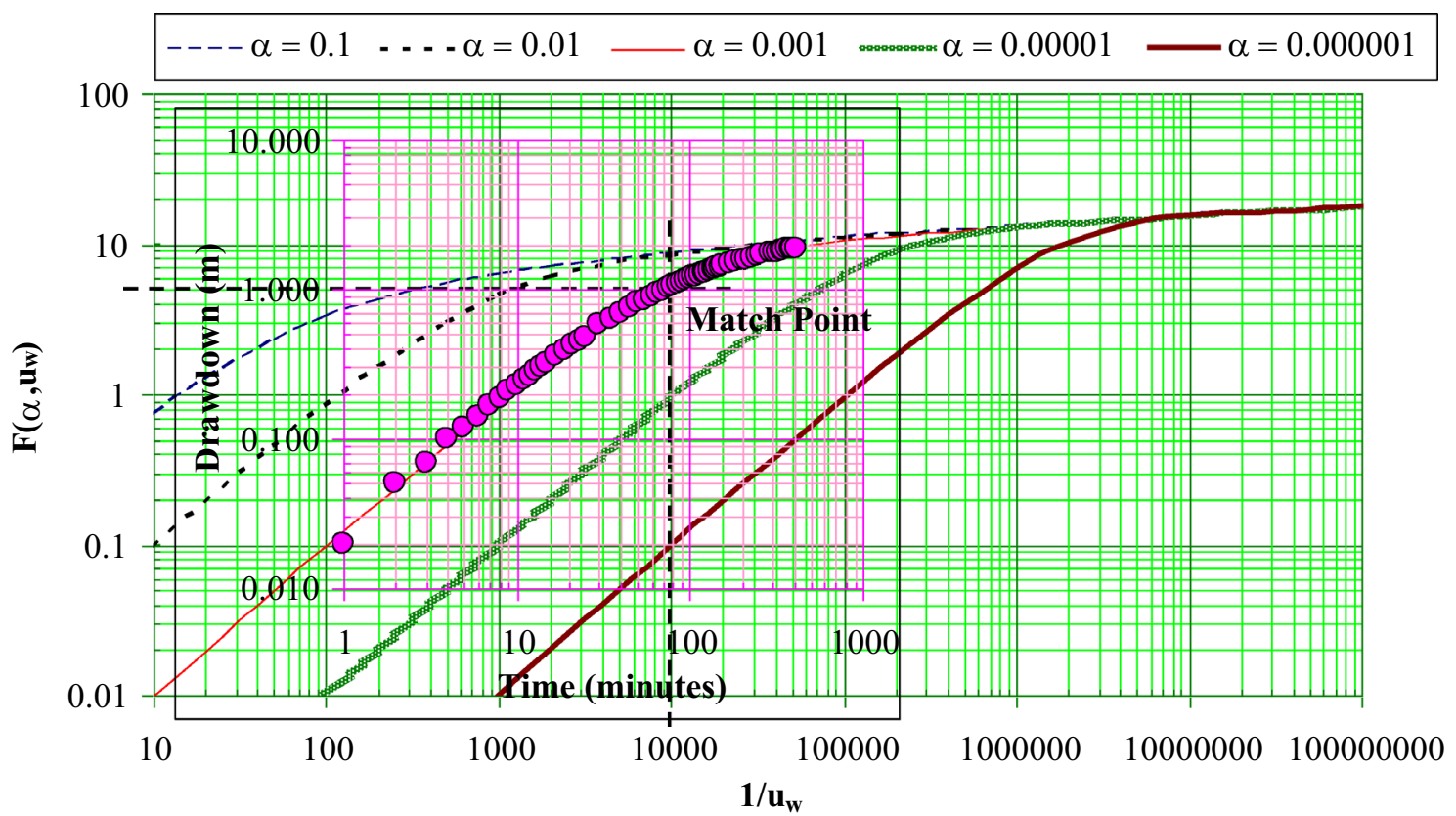

Fig. 10 Matching of observed time-drawdown curve with theoretical Papadopulos-Cooper-type curve for the Site Kushalbagh, Udaipur

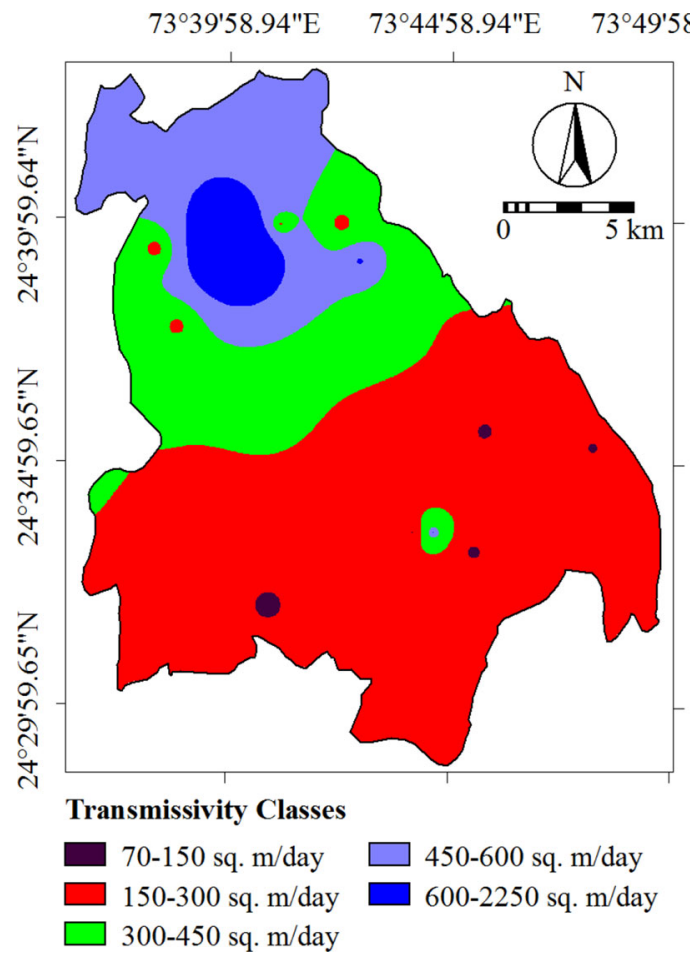

Fig. 11 Spatial distribution of transmissivity in study area

lowest specific yield values $(<0.01)$ are found to be present (in $29.3 \%$ of the entire area) in the southern and southeast portions. From the above discussion, it is clear that both the aquifer parameters showed a great spatial variation. However, spatial distribution of both the parameters is almost identical in the area.

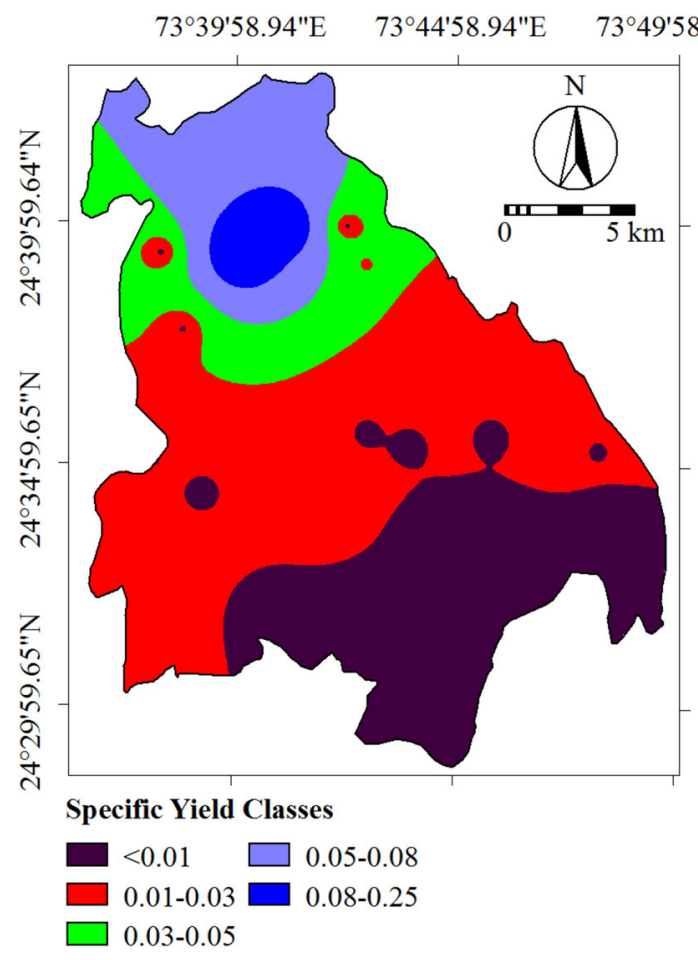

Fig. 12 Spatial distribution of specific yield in study area

\section{Spatial distribution of actual groundwater recharge}

The GIS-based actual groundwater recharge was estimated for 3 years (2006-2008) on pixel-by-pixel basis using the raster maps of both the groundwater fluctuation and the specific yield. The recharge for every pixel was estimated 
(a) Year 2006 $73^{\circ} 40^{\prime} 00.53 " \mathrm{E}$

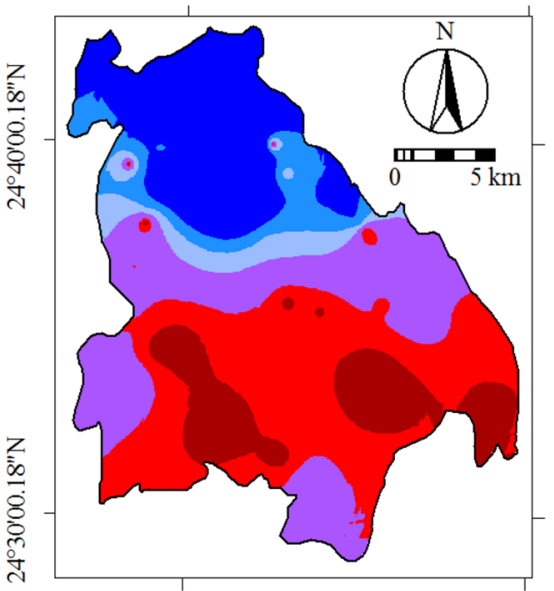

Groundwater Recharge Classes

$\square<5 \mathrm{~cm}$

$5-10 \mathrm{~cm}$ (b) Year 2007

$73^{\circ} 50^{\prime} 00.53^{\prime \prime} \mathrm{E} \quad 73^{\circ} 40^{\prime} 00.53^{\prime \prime} \mathrm{E}$

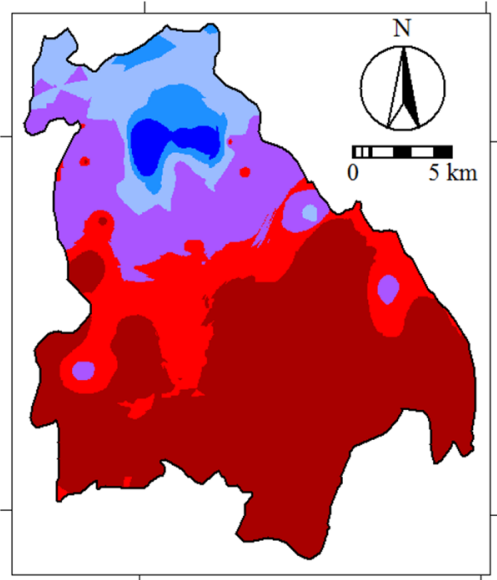

(c) Year 2008

$73^{\circ} 50^{\prime} 00.53^{\prime \prime} \mathrm{E} \quad 73^{\circ} 40^{\prime} 00.53$ "E

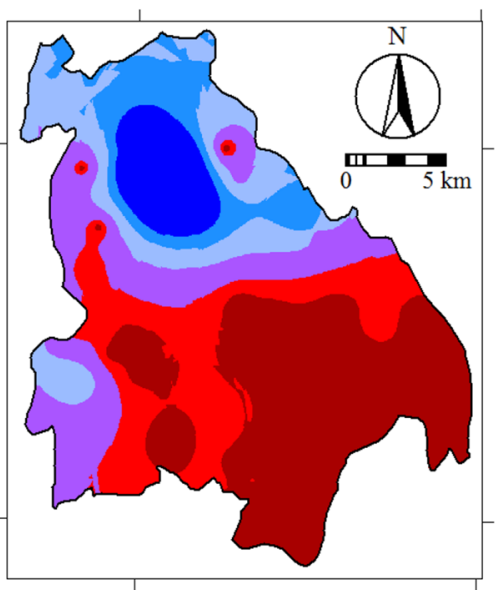
$73^{\circ} 50^{\prime} 00.53^{\prime \prime} \mathrm{E}$

Fig. 13 Groundwater recharge in study area during 2006, 2007 and 2008

by multiplying the groundwater level fluctuation for a pixel with the corresponding specific yield value for that pixel. The classified maps of the actual groundwater recharge for 3 years are shown in Fig. 13a-c.

Figure $13 \mathrm{a}-\mathrm{c}$ clearly depicts that the northern portion of the area receives considerable quantities (more than $30 \mathrm{~cm}$ ) of the groundwater recharge in all the 3 years. In the northern portion, both the transmissivity and specific yield were also very high as it is seen from Figs. 11 and 12, respectively. Considering the relatively higher topographic elevations (Fig. 1) and presence of the deep buried pediment type of geomorphology along with the high recharge occurrences, the northern portion acts as recharge zone for the entire catchment.

On comparing the recharge distribution in 3 years, it is found that the recharge in the year 2006 was very high (more than $40 \mathrm{~cm}$ ) in $21 \%$ of the area, whereas the very high recharge was confined in only 2 and $7 \%$ of the total area in the years 2007 and 2008, respectively. Conversely, the area under the recharge class of less than $5 \mathrm{~cm}$ was only $13 \%$ in the year 2006, which increased up to 52 and $34 \%$ in the years 2007 and 2008, respectively. The annual variations in distribution of the groundwater recharge are obviously due to variability of the annual rainfall $(984,494$ and $572 \mathrm{~mm}$ in the years 2006, 2007 and 2008, respectively).

The lowest quantities of the water (less than $10 \mathrm{~cm}$ ) get recharged from the southern and southwest portions and from small patches in southeast portion (Fig. 13a-c). The low recharge areas in the southern and southwest portions require suitable artificial recharge structures to augment the groundwater resources.

\section{Conclusions}

This study aimed at determining aquifer properties for a hard-rock aquifer system of India by analyzing data obtained from pumping tests conducted in large-diameter wells through spreadsheet programs. Also, the study involved estimation of distributed groundwater recharge by applying GIS and geostatistical techniques. The histograms revealed non-normality in the pre- and post-monsoon groundwater levels. The spatial distribution of the groundwater levels indicated significant influence of topography, presence of structural hills, density of pumping wells, and seasonal recharge. This finding suggests that the fast-depleting groundwater levels in the study area can be recuperated by regulating these influencing factors. Similar to the groundwater levels, their fluctuation between preand post-rainy seasons showed fair linkages with rainfall occurrences.

The developed spreadsheet programs were found reliable for analyzing the pumping test data based on satisfactory values of root mean square error, i.e., 0.017-0.339 $\mathrm{m}$ and significantly high values of correlation coefficient, i.e., more than 0.95. The analyzed pumping test data revealed that transmissivity ranges from 68 to $2239 \mathrm{~m}^{2} /$ day, whereas the specific yield varies from 0.211 to $0.51 \times 10^{-5}$. The wide spatial variations of both the parameters suggest heterogeneity, which is a general characteristic of the hard-rock aquifer systems. The possible and most likely causes for the site-specific low and high values of the aquifer properties in the study area may be fracture density, fracture length, openings and soil texture. The northern portion situated at higher ground 
elevation (575-700 $\mathrm{m} \mathrm{MSL)}$ with the high values of specific yield (0.08-0.25) and transmissivity (>600 $\mathrm{m}^{2} /$ day) acts as a recharge zone. This finding is further confirmed from the spatial distribution map of groundwater recharge with high recharge values in the northern portion, where deep buried pediments are present. The recharge was found to be related to the rainfall.

Moreover, the findings of this study may be useful to the planners, managers and decision-makers to develop suitable strategies for water resources planning and management in the study area. Also, the spreadsheet programs developed here may be utilized to analyze the pumping test data of the large-diameter wells in other hard-rock regions of the world.

Acknowledgments The present study was carried out as part of the All India Coordinated Research Project on Groundwater Utilization, Directorate of Water Management, Indian Council of Agricultural Research (ICAR), Bhubaneswar, India. The commendable efforts made by the Agricultural Supervisors, Sh. Jamuna Shankar Sharma and Sh. Sombir Singh in selecting wells and monitoring their water levels are highly appreciated. The authors are grateful to the reviewers for their kind and appreciable comments, which helped improving the earlier version of this article.

Open Access This article is distributed under the terms of the Creative Commons Attribution 4.0 International License (http:// creativecommons.org/licenses/by/4.0/), which permits unrestricted use, distribution, and reproduction in any medium, provided you give appropriate credit to the original author(s) and the source, provide a link to the Creative Commons license, and indicate if changes were made.

\section{References}

Allison GB (1988) A review of some of the physical, chemical, and isotopic techniques available for estimating groundwater recharge. In: Simmers I (ed) Estimation of natural groundwater recharge. Reidel, Dordrecht

Balkhair KS (2002) Aquifer parameters determination for large diameter wells using neural network approach. J Hydrol 265:118-128

Barker JA (1988) A generalized radial flow model for hydraulic tests in fractured rock. Water Resour Res 24:1796-1804

Bhuiyan C, Singh RP, Flügel WU (2009) Modelling of ground water recharge-potential in the hard-rock Aravalli terrain, India: a GIS approach. Environ Earth Sci 59(4):929-938

Boulton NS, Streltsova TD (1977) Unsteady flow to a pumped well in a two-layered water bearing formation. J Hydrol 35:245-256

CGWB (1997). Ground water resource estimation methodology1997. Report of the ground water resource estimation committee, Central Ground Water Board (CGWB), Ministry of Water Resources, Government of India, New Delhi, India

Charbeneau RJ (2000) Groundwater hydraulics and pollutant transport. Prentice Hall Inc, New Jersey, pp 91-178

Cherkauer DS (2004) Quantifying groundwater recharge at multiple scales using PRMS and GIS. Ground Water 42(1):97-110

Çimen M (2001) A simple solution for drawdown calculation in a large-diameter well. Ground Water 39(1):144-147
Civita M, De Maio M (2001) Average groundwater recharge in carbonate aquifers: A GIS processed numerical model. In: Proceedings of the 7th conference on limestone hydrology and fissured media, September 2001, Besancon, France, pp 93-100

Cooper HH, Jacob CE (1946) A generalized graphical method for evaluating formation constants and summarizing well field history. Trans Am Geophys Union 27:526-534

de Marsily G (1986) Quantitative hydrogeology: groundwater hydrology for engineers. Academic Press, New York

Delhomme JP (1978) Kriging in the hydrosciences. Adv Water Resour 1(5):252-266

Edmunds WM, Gaye CB (1994) Estimating the spatial variability of groundwater recharge in the Sahel using chloride. J Hydrol 156:47-59

Fayer MJ, Gee GW, Rockhold ML, Frehley MD, Walters TB (1996) Estimating recharge rates for groundwater model using GIS. J Environ Qual 25:510-518

Gringarten AC, Witherspoon PA (1972) A method of analyzing pump test data from fractured aquifers. Percolation through Fissured Rock, Deutsche Gesellschaft fur Red and Grundbau, Stuttgart, Germany, T3B1-T3B8

Hantush MS (1964) Hydraulics of wells. In: Chow VT (ed) Advances in hydroscience. Academic Press, New York, pp 281-442

Harrington GA, Cook PG, Herczeg A (2002) Spatial and temporal variability of ground water recharge in central Australia: a tracer approach. Ground Water 40(5):518-528

Healy RW, Cook PG (2002) Using ground water levels to estimate recharge. Hydrogeol J 10:91-109

ILWIS (2001) Integrated land and water information system, 3.2 academic, user's guide. International Institute for Aerospace Survey and Earth Sciences (ITC), The Netherlands, pp 428-456

Jacob CE (1944) Notes on determining permeability by pumping tests under water table conditions. Mimeographed Report, United States Geological Survey (USGS)

Jat ML (1990) Estimation of aquifer parameters in selected hydrogeological formations of Udaipur. Unpublished M.E. Thesis, Rajasthan Agricultural University, Bikaner, Rajasthan, India

Machiwal D, Jha MK (2015) GIS-based water balance modeling for estimating regional specific yield and distributed recharge in data-scarce hard-rock regions. J Hydro Environ Res 9(4):554-568

Machiwal D, Singh PK (2015) Comparing GIS-based multi-criteria decision making and Boolean logic modeling approaches for delineating groundwater recharge zones. Arab J Geosci 8(12):10675-10691

Machiwal D, Jha MK, Mal BC (2011a) Assessment of groundwater potential in a semi-arid region of India using remote sensing, GIS and MCDM techniques. Water Resour Manag 25(3):1359-1386

Machiwal D, Nimawat JV, Samar KK (2011b) Evaluation of efficacy of groundwater level monitoring network by graphical and multivariate statistical techniques. J Agric Eng ISAE 48(3):36-43

Machiwal D, Mishra A, Jha MK, Sharma A, Sisodia SS (2012) Modeling short-term spatial and temporal variability of groundwater level using geostatistics and GIS. Nat Resour Res 21(1):117-136

Machiwal D, Rangi N, Sharma A (2015) Integrated knowledge- and data-driven approaches for groundwater potential zoning using GIS and multi-criteria decision making techniques on hard-rock terrain of Ahar catchment, Rajasthan, India. Environ Earth Sci 73(4):1871-1892

NABARD (2006) Review of methodologies for estimation of ground water resources in India. National Bank for Agriculture and Rural Development (NABARD), Technical Services Department, Mumbai

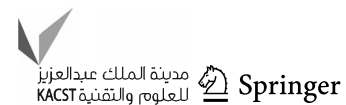


Narasimhan T (1968) Pumping tests in open wells in Palar alluvium, near Madras city, India - an application of Papadopulos-Cooper method. Bull Int Assoc Sci Hydrol 13(4-12):91-105

Neuman SP (1974) Effect of partial penetration on flow in unconfined aquifers considering delayed gravity response. Water Resour Res 10:303-312

Papadopulos IS (1967) Drawdown distribution around a large diameter well. In: Proceedings of the national symposium on ground-water hydrology, San Francisco, CA, November 1967, pp 157-168

Papadopulos IS, Cooper HH (1967) Drawdown in a well of large diameter. Water Resour Res 3(1):241-244

Patel SC, Mishra GC (1983) Analysis of flow to a large diameter well by a discrete kernel approach. Ground Water 21(5):573-576

Ratez J, Brenčič M (2005) Comparative analysis of single well aquifer test methods on the Mill Tailing site of Boršt Žirovski vrh, Slovenija. RMZ Mater Geoenviron 52(4):669-684

Reed JD (1980) Type curves for selected problems of flow to wells in confined aquifers. Techniques of Water-Resources Investigations (TWRI 3-B3), United States Geological Survey, Washington, p 106

Renard P (2005) The future of hydraulic tests. Hydrogeol J 13:259-262

Risser DW, Gburek WJ, Folmar GJ (2009) Comparison of recharge estimates at a small watershed in east-central Pennsylvania, USA. Hydrogeol J 17:287-298
Robins NS (1998) Recharge: the key to groundwater pollution and aquifer vulnerability. In: Robins NS (ed) Groundwater pollution, aquifer recharge and vulnerability. Geological Society, London, pp 1-5 (Special Publications No. 130)

Rushton KR (2003) Groundwater hydrology: conceptual and computational models. Wiley, Chichester

Rushton KR, Holt S (1981) Estimating aquifer parameters for large diameter wells. Ground Water 19(5):505-509

Sakthivadivel R, Rushton KR (1989) Numerical analysis of large diameter wells with a seepage face. J Hydrol 107:43-55

Scanlon BR, Healy RW, Cook PG (2002) Choosing appropriate techniques for quantifying groundwater recharge. Hydrogeol $\mathbf{J}$ 10:18-39

Singh VS (2000) Well storage effect during pumping tests in an aquifer of low permeability. Hydrol Sci J 45(4):589-594

Singh S (2002) Water management in rural and urban areas. Agrotech Publishing Academy, Udaipur 192 p

Sophocleous MA (1992) Groundwater recharge estimation and regionalization: the great bend prairie of central Kansas and its recharge statistics. J Hydrol 137:113-140

Theis CV (1935) The relation between the lowering of the piezometric surface and the rate and duration of discharge of a well using ground water storage. Trans Am Geophys Union 16:519-524

Warren JE, Root PJ (1963) The behaviour of naturally fractured reservoirs. Eng J 3:245-255 